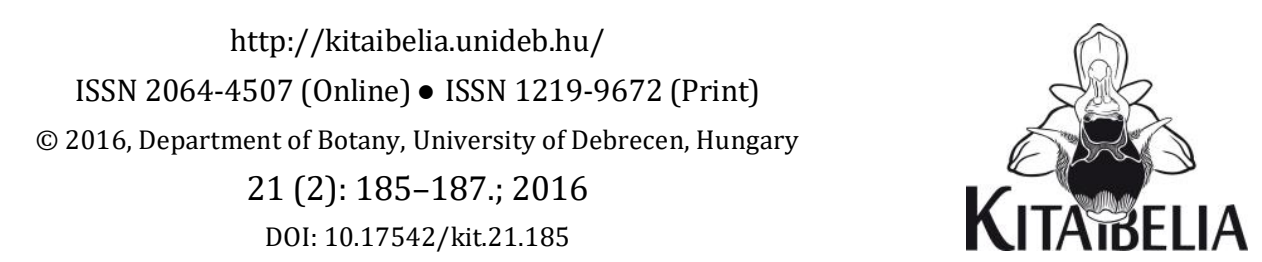

\title{
Nagyapám, dr. Polgár Sándor
}

\author{
MEnZl Anna \\ Zürich; menzla@hotmail.com
}

\section{Dr. Sándor Polgár, my grandfather}

\begin{abstract}
My grandfather, dr. Sándor Polgár was the second son of a Jewish family the members of which were at home in northwestern Hungary since generations as were the family of his wife Margit Csillag. He attended Benedictine secondary school in Győr and completed his studies at the Faculty of Sciences in Budapest where he got a teaching diploma for sciences at secondary school level. After that he obtained his PhD degree in aquatic plants. Beside science and pedagogy he was also interested in philosophy and music and he spoke fluent German and French. A number of his students became later successful scientists in Hungary and abroad. He was murdered together with my grandmother and a large number of his family members in Auschwitz.
\end{abstract}

Keywords: Győr, history of $20^{\text {th }}$ century, Hungarian botany, Hungary

Összefoglaló - Nagyapám, dr. Polgár Sándor egy zsidó család második gyermekeként született. Családja, mint felesége, Csillag Margit családja generációk óta Győr megyében éltek. Tanulmányait a Győri Bencés Gimnáziumban folytatta, majd a Budapesti Tudományegyetemen szerzett tanári diplomát. Később vízi növényekkel kapcsolatos kutatásai révén doktori fokozatot is szerzett. A tudomány és az oktatás mellett foglalkoztatta a filozófia és a zene is. Folyékonyan beszélt németül és franciául. Tanítványai sorából nemzetközileg elismert tudósok kerültek ki. Polgár Sándort feleségével és a család más tagjaival együtt Auschwitz-ban ölték meg.

Kulcsszavak: 20. század történelme, Győr, Magyarország

Nagyapám munkásságának két fő pontját a botanikai kutatás és a tanári-pedagógiai tevékenység jelentette. Botanikai munkásságáról saját publikációi, kollégák és tanítványok emlékiratai tanúskodnak. Tanári munkájáról, diákjai érdeklődésének felkeltéséről, szociális beállítottságáról, különösen szegényebb diákokkal szemben, már tbben beszámoltak (vö. SchmidT 2016, és az ott idézett irodalmak). Diákjai közül többen választották a természettudományi pályát és ezen a területén komoly sikereket értek el, például Leslie Zechmeister (Caltech) és Winter Ernő vegyészmérnökök, valamint Zólyomi Bálint botanikus. Az évek folyamán szerencsém volt kevésbé ismert diákjaival is találkozni, akik kivétel nélkül nagy tisztelettel, sőt szeretettel emlékeztek nagyapámra. Egyöntetűen hangsúlyozták rendkívüli szorgalmát, kötelességtudását és magas erkölcsi színvonalát. A kollégákból és a tanítványokból az évek folyamán sokszor barátok lettek, akik több megemlékezésben méltatták jellemét is (BOROS 1955, GRÁBICS 1984, ZóLYOMI 1988).

Én a háború alatt születtem, tehát személyes emlékem nincs nagyapámról. Amit itt leírok, azt a néhány életben maradt családtagtól, főleg anyámtól és kortársaitól hallottam. Ők is, kivétel nélkül nagy tisztelettel és megbecsüléssel beszéltek Sándorról vagy a „tanár úrról”. Mint magánembert persze családja ismerte legjobban. 
Úgy nagyapám, mint nagyanyám (született Csillag Margit) családja generációk óta Győrés Komárom megyében éltek, ahol otthon érezték magukat.

Nagyapám Győrött született, apja, Pollák Farkas neve már 1844-ben feltűnt Győrött, illetve Bőnyben. A család tudta szerint Bőnyben egy ideig bírói tisztséget töltött be. Amikor a zsidótörvények a 20. század elején kötelezték a zsidókat, hogy iratokkal bizonyítsák be magyarságukat, az okmányokból kiderült, hogy Pollák Farkas részt vett az 1848-as magyar szabadságharcban és Komáromban Klapka alatt szolgált. A győri Hitközség anyakönyveiből tudom, hogy Pollák Farkas 1876-ban - amikor a törvény ezt megengedte - Polgárra magyarosította nevét (m. kir. Belügyminisztérium 6487/900 rend.). Felesége, nagyapám anyja, Teller Katalin Komáromból származott.

Nagyanyám Ászáron született, ahonnan a család 7 gyermekével később Győrbe költözött. így gyermekkoromban sokszor hallottam e környék településeiről, Bőnyről, Mórról, Ászárról, Kisbérről.

Az érettségiig nagyszüleim mindketten Győrött éltek. Nagyapámat, mint bátyját, Polgár Viktort (Polgár Dénes újságíró apja) a Bencés Gimnáziumba iratták be, ami akkoriban Győrött a legjobb középiskola volt. Miután ebben az időben még nem létezett leánygimnázium, nagyanyám, húgai és lány unokatestvérei „hospitáltak” a gimnáziumban, azaz az osztályterem hátsó részén, feleltetés nélkül vettek részt az órákon és egyénileg tették le az érettségi vizsgákat.

Az érettségi után nagyapám a Budapesti Tudományegyetemen folytatta tanulmányait, míg nagyanyám a Középiskolai Tanárképző Intézetben készült a tanári pályára, amit mint férjes asszony később, nagy sajnálatára, nem gyakorolhatott.

Az egyetemen nagyapám Mágócsy-Dietz Sándor asszisztense lett. 1900-ban természetrajzból, vegytanból és földrajzból szerzett tanári oklevelet és ugyanebben az évben elkezdte tanári pályafutását szülővárosában, a Főreáliskolában. Doktori disszertációját „Győr vidékének vízi és vízparti edényes növényzete" címmel, már mint végzett tanár adta be.

Nagyszüleim érdeklődése széleskörű volt. Házasságuk első éveiben igyekeztek bejárni Európát. Ilyenkor az anyagi lehetőségeiknek megfelelően, az Üdvhadsereg házaiban szálltak meg.

Később, 1909 után, amikor első gyermekük, édesanyám megszületett, nagyapám folytatta botanikai célú utazásait. Így eljutott északon Helgolandig és délen Krétáig. Ezek az utazások a 20. század elején természetesen sokkal nehézkesebbek voltak, mint napjainkban. Nagyapámnak az idegennyelvű környezet nem jelentett nehézséget, hiszen kitűnő latin tudásán kívül folyékonyan beszélt németül és franciául is. A szakirodalmat ezen kívül még más nyelveken is olvasta.

Széleskörü érdeklődése a saját szakmáján kívül kiterjedt egészen más területekre is, ahol meglepően haladó gondolatvilága volt. Olvasta és nagyon értékelte Ortega y Gasset műveit. A spanyol filozófus, aki elítélte Franco uralmát és ezért emigrálni kényszerült, körülbelül nagyapám

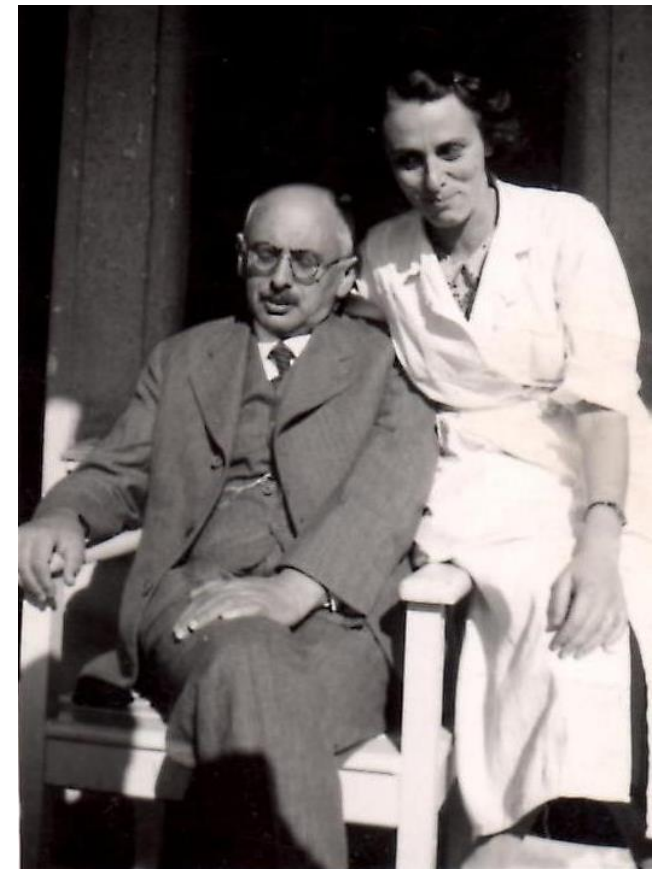

1. ábra. Polgár Sándor, lánya társaságában a győri Gráb Gyárnál, 1938-ban

Fig. 1. Sándor Polgár with his daughter, at the Gráb Factory in 1938 
kortársa volt és a filozófia egy modern irányzatát képviselte. Miután akkor magyar fordítás műveiről nem létezett, gondolom német nyelven olvasta őket.

Nagyapám szerette a zenét. Ízlése itt is haladó volt. Kedvenc operája Bizet Cármen-ja akkoriban még nem felelt meg az általános polgári ízlésnek. De nagyszüleim aktívan is részt vettek a zenei életben, így nem meglepő, hogy Bartók Bélát, amikor utolsó győri hangversenye alkalmából a városban tartózkodott, otthonukban vendégül látták.

Kirándulásairól kollégákkal és diákokkal már Boros Ádám és mások beszámoltak. Családi kirándulások nagyrészt a Bakonyba vezettek; a botanikai megfigyelés ezeken a kirándulásokon is fontos volt. Gyakori cél volt a Cuha völgye, amit gyermekkoromban szintén az ő nyomán gyakran meglátogattunk, kiindulva Vinye-Sándormajorból, ahol a kulacsunkat a forrásnál friss vízzel töltöttük fel. A gyalogtúrákon kívül a győri folyókon tett családi evezős kirándulások szintén lehetőséget adtak botanikai megfigyelésekre.

Az ember nem gondolná, hogy egy gyár kietlen környéke is növénytani érdekességeket rejt. De nagyapám fölfedezte, hogy az olajgyár udvarán, ahova Bisinger sétányi lakásukból rövid sétával jutott el, behurcolt növények jelentek meg. Ezeknek magjai az importált olajmaggal kerültek erre a területre.

Nagyapám diákjai figyelmét a botanikán kívül a természettudományok más területeire is ráirányította. Ezt mutatja egy levele 1905-ből, amiben egy győri lakóház udvarán egy diákja által talált skorpiót küldött a Nemzeti Múzeum Állattani Osztályának meghatározásra.

Feleségével és családjával nyugodt, majdnem szerény életet éltek. Anyám után még két fiúgyermekük született: Imre és Ferenc. Imre már kisgyermek korában meghalt.

Orvos fiát, dr. Polgár Ferencet, 1942-ben mint munkaszolgálatost hurcolták el az orosz frontra, ahonnan két különböző haláljelentése is érkezett. Hogy tényleg hol halt meg, nem lehet tudni, mert az úgynevezett dögcédulát (a genfi egyezmények szerinti személyi igazolójegyet) már Magyarországon, megfelelő gonosz megjegyzés kíséretében elvették tőlük.

Fia halála teljesen megtörte nagyapámat. Akkor még nem tudta, hogy milyen sors vár rá, nagyanyámra és az egész győri rokonságra. Botanikus barátai, Jávorka Sándor, Soó Rezső, Zólyomi Bálint, Moesz Gusztáv, Zsák Zoltán és Boros Ádám még a nyilaskeresztesek uralma előtt együttesen kérvényt nyújtottak be, hogy nagyapám számára kivételes elbánást eszközöljenek ki. Mint anyámtól tudom, az engedélyt megadták, de valaki „elfektette” és csak a háború után került elő.

Így nagyapámat sok megaláztatás után feleségével és más családtagokkal 1944-ben Auschwitzban ölték meg. Korai brutális halála engem még ma is végtelen szomorúsággal tölt el.

\section{Irodalom}

Boros Á. (1955): Polgár Sándor emlékezete. - Botanikai Közlemények 46: 21-24.

GRÁBICS F. (1984): Régi győri pedagógusok: Polgár Sándor (1876-1944). - Hogyan? 1984 (2): 28-32.

Schмidт D. (2016): Szívvel és alázattal. 140 éve született dr. Polgár Sándor (1876-1944). - Kitaibelia 21 (2): 169-184.

Zólyomi B. (1988): Dr. Polgár Sándor (1876-1944). - Révai Miklós Gimnázium 200. jubileumi évkönyve. pp. 97-99. 